\title{
Using Nitrogen and Oxygen Isotope Compositions of Nitrate to Distinguish Contaminant Sources in Hanford Soil and Groundwater
}

\author{
Mark Conrad and Markus Bill \\ Center for Isotope Geochemistry \\ Mailstop 70A-4418 \\ Lawrence Berkeley National Laboratory \\ Berkeley, CA 94720 \\ (510) 486-6141, MSConrad@lbl.gov
}

\section{Introduction}

The nitrogen $\left(\delta^{15} \mathrm{~N}\right)$ and oxygen $\left(\delta^{18} \mathrm{O}\right)$ isotopic compositions of nitrate in the environment are primarily a function of the source of the nitrate. The ranges of isotopic compositions for nitrate resulting from common sources are outlined in Figure 1 from Kendall (1998). As noted on Figure 1, processes such as microbial metabolism can modify the isotopic compositions of the nitrate, but the effects of these processes are generally predictable.

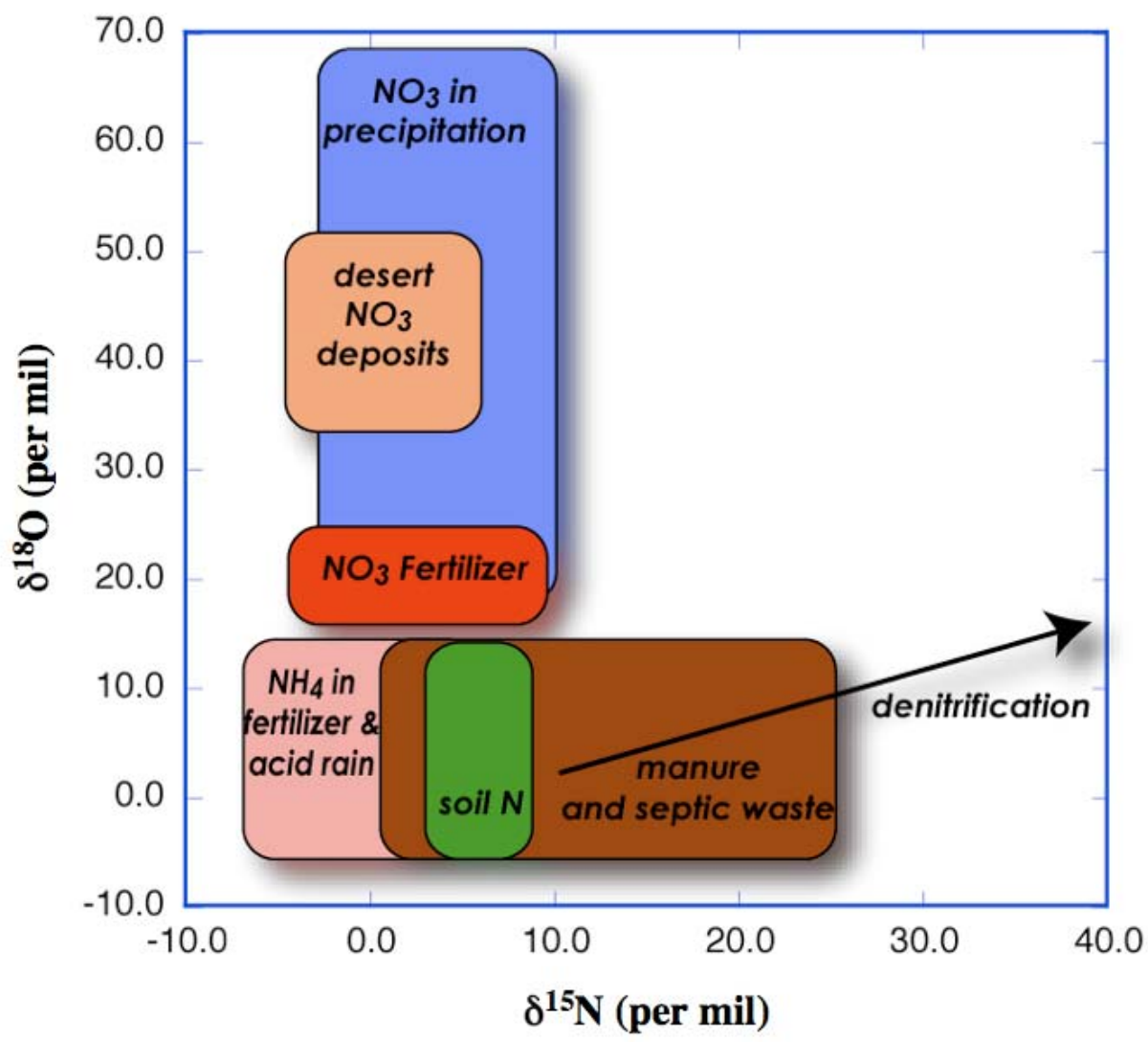

Figure 1. Range of nitrogen and oxygen isotopic compositions of nitrate in the environment (modified from Kendall, 1998).

At Hanford, nitrate and other nitrogenous compounds were significant components of most of the chemical processes used at the site. Most of the oxygen in nitrate chemicals (e.g., nitric acid) is derived from atmospheric oxygen, giving it a significantly higher $\delta^{18} \mathrm{O}$ value $(+23.5 \%)$ than naturally occurring nitrate that obtains most of its oxygen from water (the $\delta^{18} \mathrm{O}$ of Hanford 
groundwater ranges from $-14 \%$ to $-18 \%$ o). This makes it possible to differentiate nitrate from Hanford site activities from background nitrate at the site (including most fertilizers that might have been used prior to the Department of Energy plutonium production activities at the site). In addition, the extreme thermal and chemical conditions that occurred during some of the waste processing procedures and subsequent waste storage in select single-shell tanks resulted in unique nitrate isotopic compositions that can be used to identify those waste streams in soil and groundwater at the site (Singleton et al., 2005; Christensen et al., 2007). This report presents nitrate isotope data for soil and groundwater samples from the Hanford 200 Areas and discusses the implications of that data for potential sources of groundwater contamination.

\section{Analytical Methods}

The $\delta^{15} \mathrm{~N}$ and $\delta^{18} \mathrm{O}$ values of groundwater and sediment samples (collected from cores or grab samples during drilling) have been analyzed. Nitrate was extracted from the sediment samples using a 1:1 mixture of sediment and de-ionized water. Groundwater samples were collected during normal groundwater monitoring activities following standard sampling procedures. The isotopic compositions of the nitrate were analyzed at the Center for Isotope Geochemistry (CIG) at LBNL using a bacterial method for simultaneous measurement of the nitrogen and oxygen isotopic ratios of the nitrate (Sigman et al., 2001; Casciotti et al., 2002). Briefly, a denitrifying bacteria, Pseudomonas chlororaphi, with a truncated reaction pathway is used to convert dissolved $\mathrm{NO}_{3}{ }^{-}$to gaseous $\mathrm{N}_{2} \mathrm{O}$ in sealed reaction vials. The $\mathrm{N}_{2} \mathrm{O}$ produced is flushed from the vials, concentrated and introduced into a mass spectrometer in continuous-flow mode. This technique allows rapid analysis of low concentrations $(<1 \mathrm{mg} / \mathrm{L})$ of nitrate with minimal sample preparation. The isotopic compositions of the nitrate are reported using the standard $\delta$ notation with parts per mil (\%o) variations from the international standards (AIR for nitrogen isotopes and Vienna Standard Mean Ocean Water or VSMOW for oxygen isotopes) where, for nitrogen:

$$
\left.\delta^{15} \mathrm{~N}_{\mathrm{AIR}}=\left[\left({ }^{15} \mathrm{~N} /{ }^{14} \mathrm{~N}\right)_{\text {sample }} /\left({ }^{15} \mathrm{~N} /{ }^{14} \mathrm{~N}\right)\right)_{\mathrm{AIR}}-1\right] \times 1000
$$

Analyses of standards with known isotopic compositions during each sample set are used to correct the measured isotopic compositions of the unknown samples for the effects of fractionation during microbial conversion of nitrate to $\mathrm{N}_{2} \mathrm{O}$. The precision of the results $(1 \sigma)$ based on repeated analyses of the standards are $\pm 0.5 \%$ o for nitrogen isotope data and $\pm 0.6 \%$ o for oxygen isotope data.

\section{LBNL Nitrate Isotope Studies in the Hanford 200 Areas}

The nitrate isotopic compositions of several hundred sediment and groundwater samples from Hanford have been analyzed over the last 4 years at the Center for Isotope Geochemistry (CIG) at LBNL. The initial nitrate isotope study was funded as part of an EMSP (now ERSP) grant to test the utility of nitrate isotopic signatures for identifying the sources of nitrate contamination in the groundwater (Singleton et al., 2005). One of the key results of this work was the discovery that nitrate from single-shell tank releases in the WMA T area (from T-106 and TX-104 release events) had anomalously high $\delta^{15} \mathrm{~N}$ values without the high $\delta^{18} \mathrm{O}$ values normally associated with low-activity, chemical wastes generated at the Hanford site. These tank releases also included relatively high concentrations of ${ }^{99} \mathrm{Tc}$, presenting the possibility that the unique isotopic signature of the nitrate could be used to identify the source of both the nitrate 
and the associated ${ }^{99} \mathrm{Tc}$ in groundwater. Additional analyses of nitrate isotope samples have since been funded by the Hanford Science and Technology program to help identify the sources of high ${ }^{99}$ Tc concentrations recently discovered in the northeast section of the WMA T area.

The cause of the distinctive isotopic signature of the WMA T tank leak nitrate is believed to be the result of processes that occurred in the single-shell tanks. The T Tank Farm tanks received waste from PUREX boiling waste tanks (in the A and AX tank farms) after the waste was allowed to boil for 2 to 3 years with replacement of water as needed to allow decay of shortlived radionuclides, and then processed through the B Plant to recover ${ }^{137} \mathrm{Cs}$ (Tom Jones, personal communication). The prolonged period of boiling probably caused the nitrogen isotope composition of the residual nitrate in the boiling tanks to become enriched in the heavier isotope of nitrogen $\left({ }^{15} \mathrm{~N}\right)$ resulting in the high $\delta^{15} \mathrm{~N}$ values observed for the nitrate. The high temperatures and extreme $\mathrm{pH}$ conditions would have also caused oxygen isotope exchange between nitrate and water. The water has a much lower $\delta^{18} \mathrm{O}$ value than chemical nitrate (approximately $-17 \%$ for water versus $+25 \%$ o for nitric acid), so the oxygen isotopic exchange in the tanks would have resulted in a significant decrease in the $\delta^{18} \mathrm{O}$ values of the nitrate.

At various times, $1^{\text {st }}$ cycle, $2^{\text {nd }}$ cycle, and 224 waste supernatants were intentionally discharged from T Farm tanks to the soil column. These were not high-activity waste types and were not associated with any "boiling wastes' (Tom Jones, personal communication). Figure 2 is a map of the WMA T area with the locations of the tanks, cribs and trenches in the area. The mixture of the leaking tank wastes with low-activity wastes containing nitrate with unaltered chemical isotopic signatures likely produced nitrate with isotopic compositions intermediate between the boiling tank waste and the low-activity chemical waste generally disposed directly to the ground through cribs and trenches. When combined with natural background nitrate, this combination produces a 3-component mixture in the groundwater.

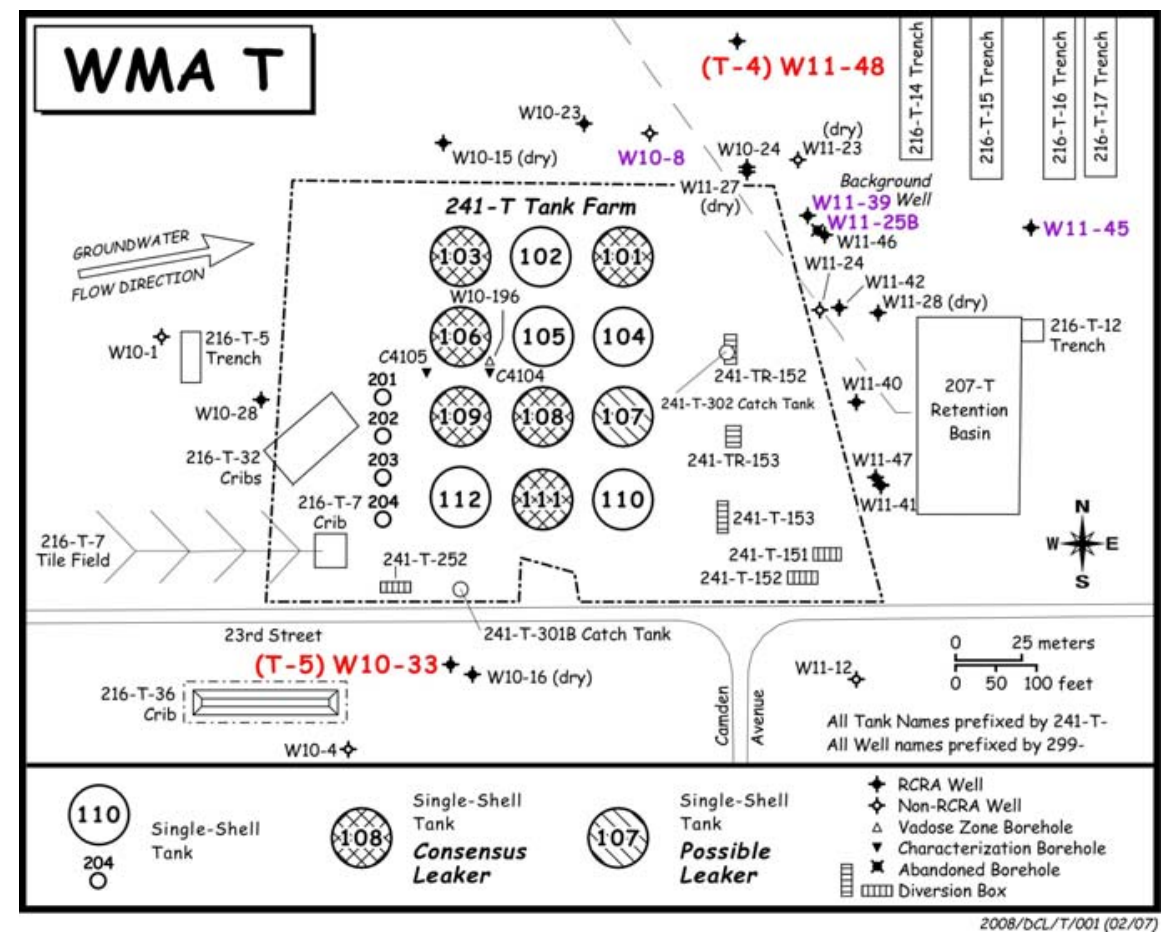

Figure 2. Map of the northern portion of the WMA $\mathrm{T}$ area including the $\mathrm{T}$ tank farm with the locations of the tanks, trenches, cribs and groundwater monitoring wells. 
The isotopic compositions of nitrate in groundwater and sediment samples collected from the WMA T area are plotted on Figure 3 with the general isotopic compositions of the 3 primary sources of nitrate in the area; natural background, low-activity chemical waste and single-shell boiling tank waste. The groundwater samples on this plot are located along a mixing line between low-activity waste and background nitrate, with the exception of groundwater from the northeast corner of the WMA T area (299-W10-8, 299-W11-39, and depth discrete samples from 299-W11-25B; see Figure 2). The groundwater samples with the highest contributions of lowlevel nitrate waste also had the highest concentrations of nitrate and the groundwater samples with apparent contributions of tank waste had elevated concentrations of ${ }^{99} \mathrm{Tc}$. A few of the pore water extracts obtained by ultracentrifugation of vadose zone core samples from 2 more recently completed wells (the locations of these wells are noted in red on Figure 2), T4 and T5, also appear to include small contributions of boiling tank waste. The isotope data for nitrate from T4, T5, and 299-W11-25B are given in the appendix. It should be noted that the $\delta^{15} \mathrm{~N}$ values of a deionized water extract and a pumped groundwater sample from the same depth in the T5 core are significantly different, likely indicating the de-ionized water extracts are dissolving some nitrate not contained in the groundwater.

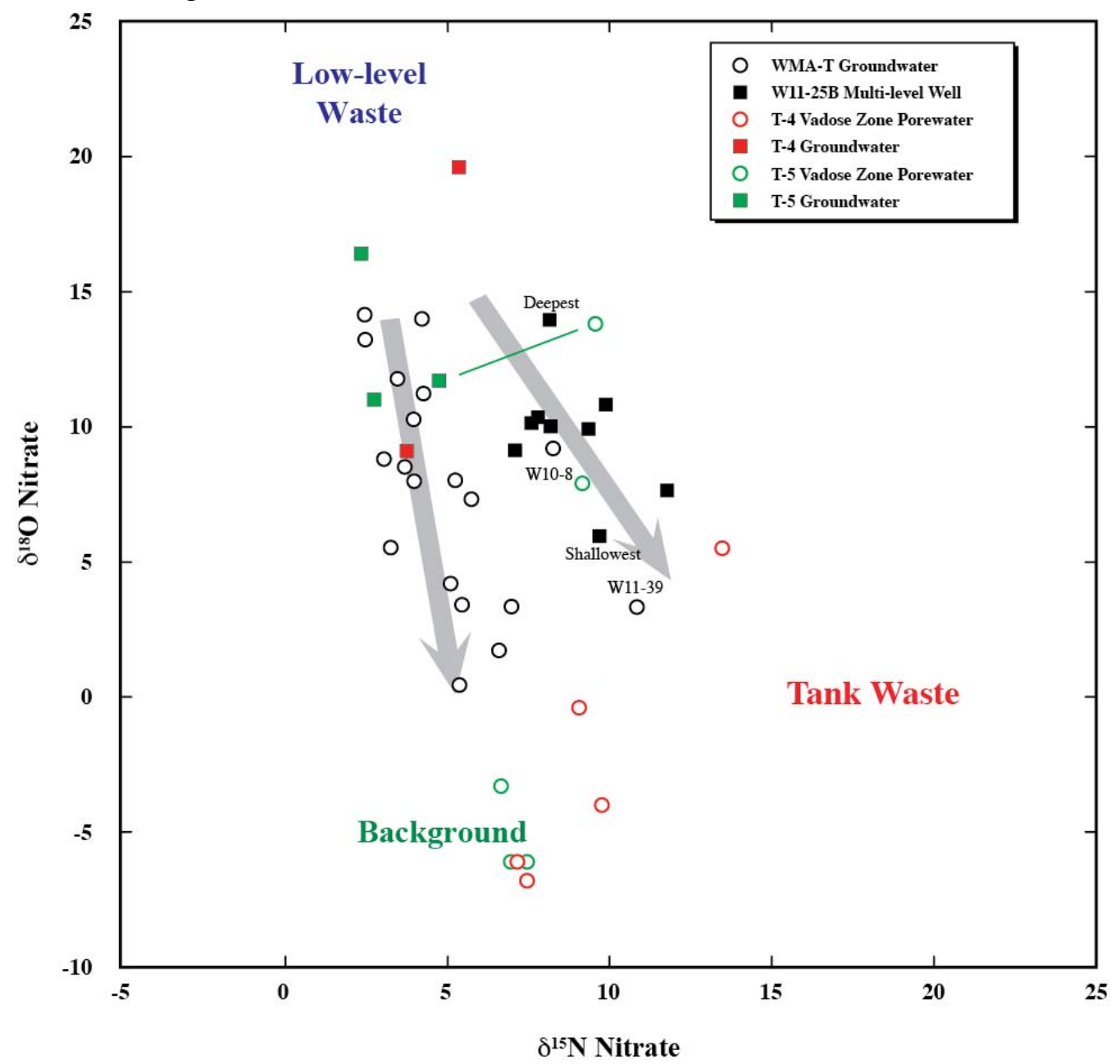

Figure 3. Nitrate and oxygen isotope data for groundwater and vadose zone core samples from the WMA $\mathrm{T}$ area. The shallowest and deepest of the groundwater samples from W11-25B are labeled on the figure. Also noted on the figure (by a green line connecting the two) are the groundwater and pore water extract samples from the same depth in the T-5 core (241 feet bgs; see Table 1). 
Two leaking tanks in the $\mathrm{T}$ tank farm that received boiling tank waste, $\mathrm{T}-101$ and $\mathrm{T}-106$, also had high ${ }^{99}$ Tc concentrations. The ratios of ${ }^{99} \mathrm{Tc}$ to nitrate in those tanks were very high relative to the ratios of ${ }^{99} \mathrm{Tc}$ to nitrate estimated for the waste discharged to the cribs and trenches proximal to the $\mathrm{T}$ tank farm (Figure 4), reflecting the high proportion of low-activity chemical waste with less ${ }^{99}$ Tc put in the cribs and trenches.

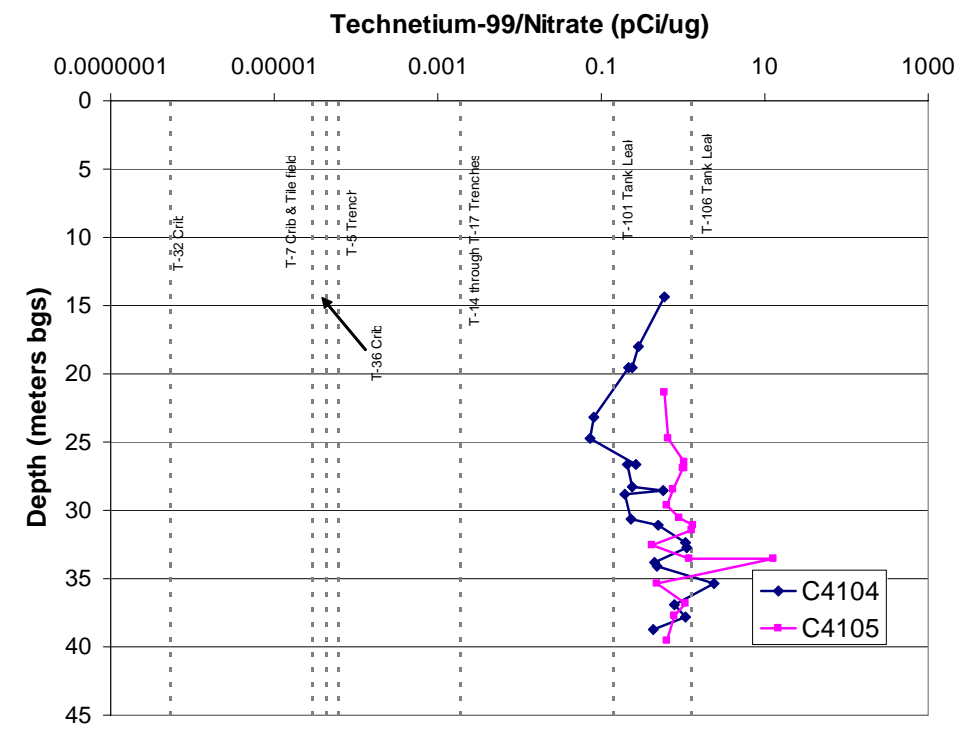

Figure 4. Estimated ratios of concentrations of ${ }^{99} \mathrm{Tc}$ to nitrate discharged to trenches and cribs in the $\mathrm{T}$ tank farm area and in tanks T-101 and T-106. Also plotted are the ${ }^{99} \mathrm{Tc} / \mathrm{NO}_{3}$ ratios in de-ionized water leaches of samples from the C4104 and C4105 cores drilled near the T-106 tank. See Figure 2 for locations of these features. Figure from Horton (2007).

The concentrations of nitrate and ${ }^{99} \mathrm{Tc}$ in groundwater sample from 299-W11-25B are compared to the isotope compositions of the nitrate in Figure 5. The peak in ${ }^{99} \mathrm{Tc}$ at $\sim 10 \mathrm{~m}$ below the groundwater surface also contains nitrate with the highest $\delta^{15} \mathrm{~N}$ value. This data suggests that the high ${ }^{99} \mathrm{Tc}$ concentrations in the groundwater in the northeast corner of the WMA T area resulted from a significant input of waste from leaks of boiling waste.
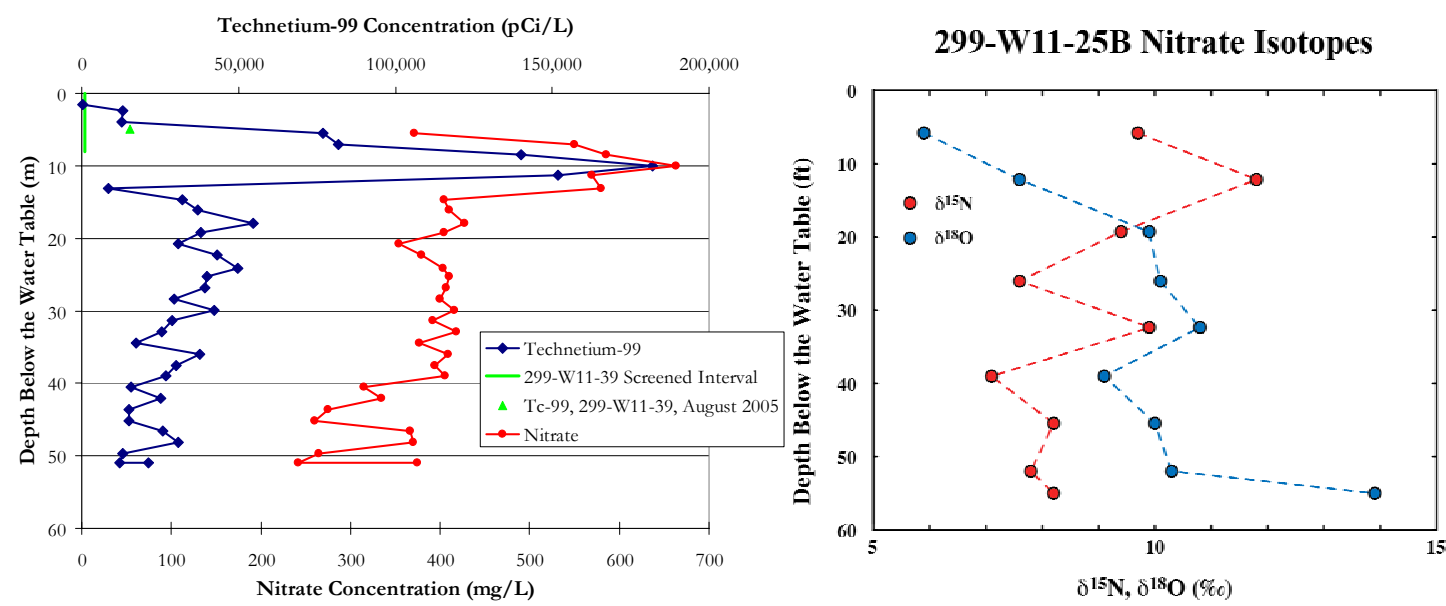

Figure 5. Plots of nitrate and ${ }^{99}$ Tc concentrations on the left (from Horton, 1999) and the nitrogen and oxygen isotope compositions of the nitrate on the right plotted versus depth below the water table in multilevel well 299-W11-25B. Note that the ${ }^{99}$ Tc peak corresponds to the highest $\delta^{15} \mathrm{~N}$ value for nitrate. 


\section{Other Nitrate Isotope Data from the 200 West Area}

Besides the samples from the WMA T area discussed above, the nitrate isotope compositions of an additional 25 Hanford groundwater samples from the 200 West Area were analyzed as part of the initial EMSP study. This data provides a baseline for identifying potential areas where boiling tank waste may be impacting groundwater. A brief summary of the results of those analyses is presented below.

200 West Tank Farm - The locations of groundwater samples from the 200 West Area with $\delta^{15} \mathrm{~N}$ values of nitrate of $>10 \%$ are plotted on Figure 6 . Besides the northeast corner of the WMA T area, there are two locations with several samples that have high $\delta^{15} \mathrm{~N}$ values that may indicate input of boiling tank waste. One area is in the vicinity of the $U$ cribs. The data are sparse in this area, but of four samples analyzed, three had high $\delta^{15} \mathrm{~N}$ values. Nitrate concentrations in these

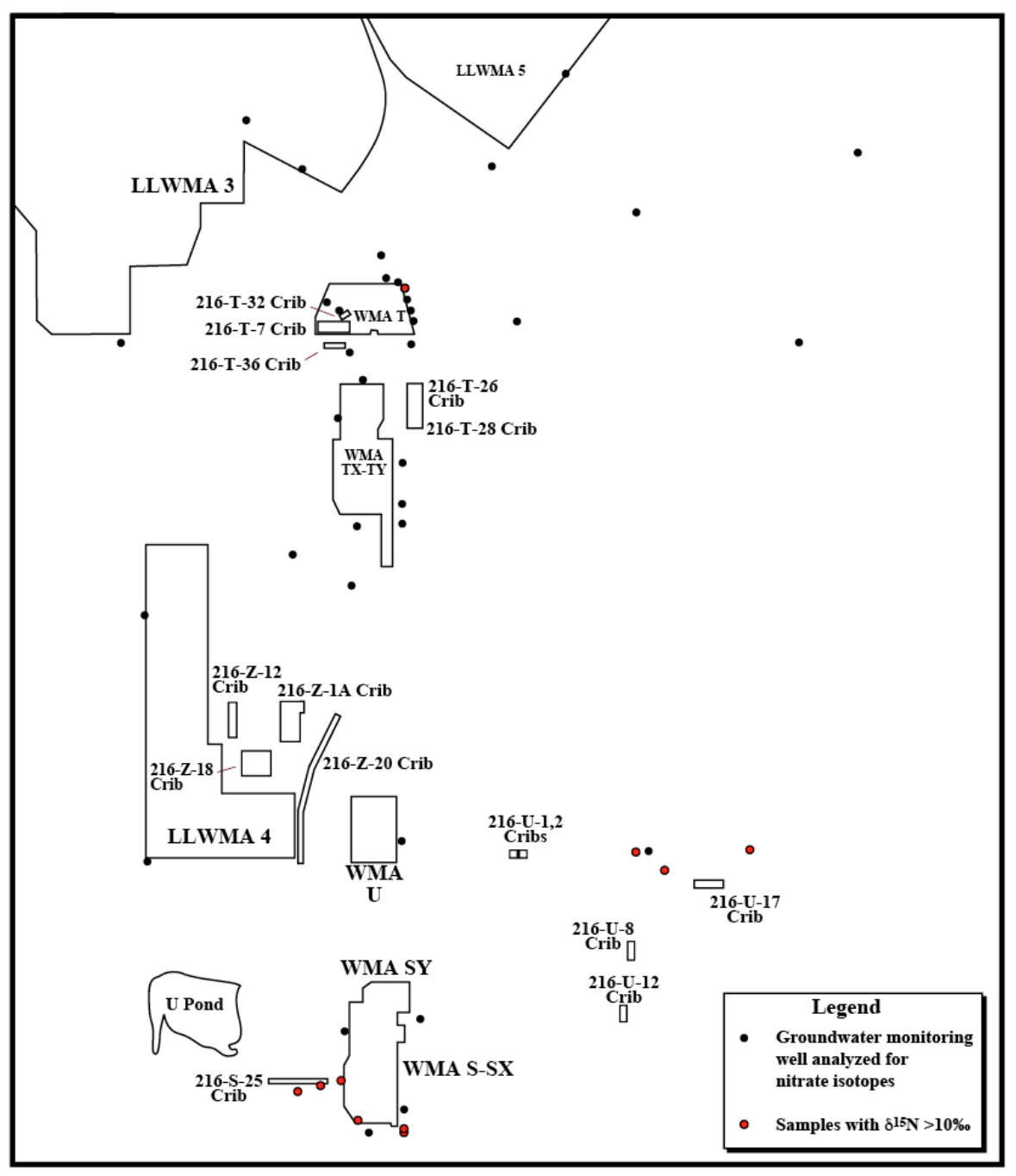

Figure 5. Map of the 200 West Area showing the location of wells sampled for nitrate isotope analyses. Wells with $\delta^{15} \mathrm{~N}$ values greater than $10 \%$ are highlighted in red.

samples were moderate ( $>100 \mathrm{mg} / \mathrm{L}$ ) and the $\delta^{18} \mathrm{O}$ values were 6 to $10 \%$. The other area of high $\delta^{15} \mathrm{~N}$ values is in the southern part of the 200 West Area, in the vicinity of the SX tank farm and 
the 216-S-25 Crib. Nitrate concentrations in these wells ranged from $22 \mathrm{mg} / \mathrm{L}$ in well W23-10 just to the south of the 216-S-25 crib to $336 \mathrm{mg} / \mathrm{L}$ in well W23-19 next to the southwest corner of the SX tank farm. The $\delta^{18} \mathrm{O}$ values of the nitrate in these wells ranged from 1.1 to $7.6 \%$. The tanks in the SX Tank Farm received high-activity boiling REDOX waste. The cribs in this area received excess condensate from the boiling waste tanks, discharges from the first cold REDOX start-up run and groundwater from the U-crib pump and treat operations in the late 1980s (Wood et al., 1999).

\section{Conclusions}

Although the amount of isotope data for nitrate in the 200 West Area is limited, there is good evidence to indicate that the $\delta^{15} \mathrm{~N}$ and $\delta^{18} \mathrm{O}$ values of the nitrate contamination in groundwater may be very useful for identifying and distinguishing between different potential sources of the nitrate. When combined with other indicators of waste processing practices (e.g., ${ }^{99} \mathrm{Tc}$ concentrations, ${ }^{99} \mathrm{Tc} / \mathrm{NO}_{3}{ }^{-}$ratios, uranium isotope compositions), the nitrate isotope data can be helpful for quantifying mixing relations between different, overlapping waste streams. Because nitrate is a highly mobile compound, the nitrate isotope data could also be a valuable precursor for determining potential pathways for transport of contaminants to groundwater.

\section{Acknowledgments}

Funding for this work was provided by the U. S. Department of Energy under contract DEAC06-76RL01830 through Fluor Hanford, Inc. and by the Director, Office of Science, Office of Biological and Environmental Research, Environmental Remediation Sciences Program, of the U.S. Department of Energy under Contract No. DE-AC02-05CH11231. Samples were provided by Evan Dresel, Jeff Serne and Chris Brown of the Pacific Northwest National Laboratory. Mike Singleton and Kate Woods analyzed the isotope compositions of the some of the earlier nitrate samples. Interpretation of the data was a joint effort between all of the people mentioned above and the authors, with several key insights provided by Tom Jones of Fluor Federal Services. An earlier version of this report was improved by reviews by Tom Jones, Duane Horton and Susan Narbutovskih. 


\section{References Cited}

Christensen, J.N., Conrad, M.E., D.J. DePaolo, and P.E. Dresel, 2007, Isotopic Studies of Contaminant Transport at the Hanford Site, WA: Vadose Zone J. 6, 1018-1030.

Horton, D.G., 2007, Data Package for Past and Current Groundwater Flow and Contamination beneath Single-Shell Tank Waste Management Areas. PNNL-15837, Pacific Northwest National Laboratory, Richland, WA.

Kendall, C. In: Kendall, C., McDonnell, J.J. (Eds.), Isotope Tracers in Catchment Hydrology. 1998. Elsevier Science, Amsterdam, pp. 519-576.

Singleton, M.J., K.N. Woods, M.E. Conrad, D.J. DePaolo, and P.E. Dresel, 2005, Tracking sources of unsaturated zone and groundwater nitrate contamination using nitrogen and oxygen stable isotopes at the Hanford Site, WA: Environ. Sci. Technol. 39, 3563-3570.

Wood M.I., V.G. Johnson, S.P. Reidel, and T.E. Jones. 1999, Subsurface conditions description For the S-SX Waste Management Area. HNF-4936, Rev. 0, Lockheed Martin Hanford Corporation, Richland, WA. 
Appendix 1. Table of isotope data for nitrate from samples collected from T4 (299-W11-48), T5 (299-W10-33) and 299-W11-25B boreholes.

\begin{tabular}{|c|c|c|c|}
\hline Sample ID & Depth (ft bgs) & $\delta^{15} \mathrm{~N}_{\mathrm{AIR}}(\%)$ & $\delta^{18} \mathrm{O}_{\text {VSMOW }}(\%)$ \\
\hline B1L476 T4 water extracted & 86 & 9.1 & -0.4 \\
\hline B1L487 T4 water extracted & 140 & 9.8 & -4.0 \\
\hline B1MB14 T4 water extracted & 206 & 13.5 & 5.5 \\
\hline B1MB17 T4 water extracted & 214 & 7.2 & -6.1 \\
\hline B1MB18 T4 water extracted & 225 & 7.5 & -6.8 \\
\hline B1L4W8 T4 groundwater & 252 & 5.4 & 19.6 \\
\hline B1L4Y3 T4 groundwater & 382 & 3.8 & 9.1 \\
\hline B1L8J0 T5 water extracted & 90 & 6.7 & -3.3 \\
\hline B1L8J5 T5 water extracted & 110 & 7.0 & -6.1 \\
\hline B1L8K5 T5 water extracted & 160 & 9.2 & 7.9 \\
\hline B1MB53 T5 water extracted & 180 & concentration too low & ----- \\
\hline B1MB60 T5 water extracted & 210 & 7.5 & -6.1 \\
\hline B1MB67 T5 water extracted & 241 & 9.6 & 13.8 \\
\hline B1L925 T5 groundwater & 241 & 2.8 & 11.0 \\
\hline B1L929 T5 groundwater & 280 & 4.8 & 11.7 \\
\hline B1L943 T5 groundwater & 400 & 2.4 & 16.4 \\
\hline B1BWD1 W11-25B groundwater & 260 & 9.7 & 5.9 \\
\hline B1BWD4 W11-25B groundwater & 279 & 11.8 & 7.6 \\
\hline B1BWD7 W11-25B groundwater & 301 & 9.4 & 9.9 \\
\hline B1BWF0 W11-25B groundwater & 321 & 7.6 & 10.1 \\
\hline B1BWB7 W11-25B groundwater & 340 & 9.9 & 10.8 \\
\hline B1BWC2 W11-25B groundwater & 360 & 7.1 & 9.1 \\
\hline B1BWB8 W11-25B groundwater & 380 & 8.2 & 10.0 \\
\hline B1BWD8 W11-25B groundwater & 400 & 7.8 & 10.3 \\
\hline B1BWX7 W11-25B groundwater & 409 & 8.2 & 13.9 \\
\hline
\end{tabular}

